\title{
Rekonstruksi Syarat Anggota Dewan Perwakilan Rakyat Dalam Perspektif Ketatanegaraan Islam
}

\author{
Muhammad Wahdini \\ Mahasiswa Program Magister Ilmu Syariah Fakultas Syariah dan Hukum \\ UIN Sunan Kalijaga Yogyakarta \\ muhammadwahdini99@gmail.com
}

\begin{abstract}
The many polemics that occur in the House of Representatives of the Republic of Indonesia (DPR RI), starting from the lack of the maximum legislative function where the Parliament is considered not productive in producing laws, instead of being productive, when producing Draft Laws actually results in highly controversial results. Like the latest Penal Code Bill, the Corruption Eradication Commission Law revised and caused turmoil in the community. Slanted news about legislative institutions in Indonesia has become a public secret, ranging from the lack of members present at meetings to those who are sleeping together and other issues. This research summarizes the opinions of thinkers in the world of Islamic state administration so that analyzing the capability or competence of DPR members is the main cause that causes a number of problems that occur. Furthermore, the concept of Islamic constitutionality answers that the professionalism and expertise aspects are the main priorities of those who fill positions in the legislature. So that there is a need to reconstruct the conditions of people who will fill the positions of DPR members needed by people who have capabilities and expertise in both the legislative, budgetary and supervisory functions. The estuary is the maximum performance of legislative members who are the presentations of all Indonesian people.
\end{abstract}

Keywords : Reconstructions, Legislative, Capability, Islamic State Administration

\section{A. PENDAhuluan}

Berbagai penelitian tentang hukum Islam dalam berbagai konteks dan berbagai bentuk, merupakan suatu upaya untuk memberi pemahaman dan menelaah serta menggambarkan berbagai bentuk dimensi dan substansi hukum Islam, sehingga menjadi sebuah unsur dari kehidupan manusia yang dapat ditelaah dari berbagai sumber. Lebih jauh, hukum Islam sebenarnya dapat diolah sebagai keilmuan yang dapat dijalankan melalui konsep interpretasi, yang sangat bermanfaat bagi pengembangan dan pembentukan pengetahuan yang bersifat ilmiah, maupun bagi permasalahan hukum untuk menjadi acuan dalam kehidupan berbangsa dan bernegara (Ashadi, 2016:3).

Salah satu bahasan yang selalu berkembang dalam konteks negara bangsa adalah lembaga legislatif atau dalam beberapa literatur fiqih siyasah disebut dengan ahl al- 
halli wa al- 'aqd dan salah satu perwujudannya di Indonesia adalah lembara Dewan Perwakilan Rakyat (DPR).

Keberadaan lembaga perwakilan di Indonesia sebagai unit lembaga yang menarik untuk diteliti. Hal ini disebabkan kehadirannya mampu mengikuti diamika dan perubahan politik yang terjadi. Sejarahnya hanya berbentuk sebuah komisi sementara bernama Komite Nasional Indonesia Pusat (KNIP) hingga menjelma menjadi Dewan Perwakilan Rakyat (DPR) dan Majelis Perwakilan Rakyat (MPR) yang mengalami berbagai dinamika kejadian politik yang beragam. Artinya, lembaga legislatif di Indonesia menjadi bagian tak terpisahkan dari perpolitikan di Indonesia yang relatif berubah-ubah, baik hubungan kelembagaannya, kewenangannya, internal lembaga, hingga fungsi yang dijalankan hingga sistem pemilihan anggotanya (Ichwanuddin, 2014:1-2). Polemik yang baru saja hangat dipermasalahkan adalah ketika Dewan Perwakilan Rakyat (DPR) yang mempunyai fungsi legislasi melakukan revisi terhadap Undang-Undang Komisi Pemberantasan Korupsi (KPK) dan merevisi beberapa Undang-Undang Kitab Undang-Undang Hukum Pidana (KUHP) yang dinilai kontroversial oleh banyak kalangan. Sehingga terjadi unjuk rasa (demonstrasi) diberbagai daerah di Indonesia menuntut pembatalan revisi RUU KPK dan RUU KUHP.

Lebih jauh lagi, Dalam menjalankan fungsinya, DPR periode 2014-2019 dinilai sangat rendah kinerjanya terutama dalam menjalankan fungsi legislasi. Fungsi legislasi diamanatkan sebagai tugas DPR selaku pemangku kekuasaan membentuk undang-undang. Fungsi ini paling strategis dan dominan, karena melalui fungsi legislasi ini DPR dapat membuat tatanan semua aspek yang ada di negara Indonesia. Namun fungsi ini ternyata dilaksanakan kurang maksimal. DPR nyatanya kurang produktif karena sedikitnya RUU yang diinisiasi oleh dewan. Padahal sebagai refresentasi rakyat, DPR dituntut untuk memaksimalkan fungsi ini untuk menciptakan kesejehtraan rakyat Indonesia (Ratnia, Witianti 2016:292). Tentunya muncul pertanyaan yang menarik untuk ditelisik, tentang sebarapa kapabel anggota DPR yang menjadi wakil rakyat di parlemen. Sehingga banyak problematika-problematika yang muncul.

Dalam penelitian yang dilakukan oleh Irmayadi sastra(Irmayadi, 2018) perlu adanya rekontruksi sistem pencalonan anggota legislatif yaitu dengan melalui tahapan kompetensi tes (Fit and Proper Test) hal itu dilakukan dalam rangka membangun kapabilitas anggota legislatif. Pada penelitian ini telah menyajikan betapa pentingnya peran anggota legislatif dalam keberlangsungan negara dan juga bagi kehidupan masyarakat bangsa, tetapi tidak diiringi dengan mekanisme rekrumen partai politik dan pemilihan umum yang memperhatikan kapabilitas calon anggota legislatif. Sehingga penelitian ini berkesimpulan perlu adanya Rekontruksi terhadap sistem pencalonan anggota legislatif, tetapi dalam penelitian ini tidak mengemukakan bagaimana pandangan ketatanegaraan islam dalam polemik yang terjadi. 
Dewasa ini kajian ketatanegaraan islam sangat berkembang pesat, sehingga penelitian ini menjadi sangat penting mengaitkan variabel kekisruhan yang terjadi dilembaga legislatif di negara Indonesia dewasa ini dalam kajian ketatanegaraan islam. Karena didalam Al-Qur'an sebagai kitab suci umat islam terdapat sejumlah ayat yang mengandung petunjuk dan pedoman bagi manusia dalam hidup bermasyarakat dan bernegara (Munawir Sjadzali , 1990:4). Lebih jauh penelitian ini akan menjadi literatur untuk menjadi salah satu kajian dan bahan serta usulan (Grand Design) bagaimana syarat anggota legislatif yang ideal dalam persepektif ketatanegaraan islam.

Secara spesifik, penelitian ini akan berfokus kepada obyek syarat calon anggota DPR yang saat ini tertuang dalam yang diterbitkan oleh Komisi Pemilihan Umum (KPU), Peraturan Nomor 20 Tahun 2018 tentang Pencalonan Anggota DPR, DPRD Provinsi, dan DPRD Kabupaten/Kota yang akan dikaji dalam perspektif ketatanegaraan islam.

\section{B. KAJIAN TEORI}

\section{Dewan Perwakilan Rakyat}

Dewan Perwakilan Rakyat Republik Indonesia merupakan salah satu lembaga tinggi Negara yang mempunyai posisi strategis di Indonesia, selain perangkat kenegaraan lain yang melaksanakan publik demokrasi ( Sholehah, Witianti, 2016:294). Dewan Perwakilan Rakyat Republik Indonesia (DPR RI) suatu lembaga negara yang masuk dalam lingkup politik hukum serta Undang-Undang sebagai manifestasi dari politik hukum tersebut. DPR RI juga memiliki kekuasaan sebagai pembentuk undang-undang sebagaimana telah termaktub dalam Undang-Udang Dasar Negara Republik Indonesia Tahun 1945 (UUD NRI 1945) pada pasal 20 ayat (1). Pada aspek sosiologis, kekuasaan tersebut adalah amanat dari seluruh rakyat Indonesia. Karena hakikatnya, rakyat mempunyai andil yang signifikan dalam pemerintah. Hal tersebut sebagai suatu karakteristik yang paling mendasar dalam pemerintahan yang menganut asas demokrasi, pemerintahan dari rakyat, oleh rakyat dan untuk rakyat. Rakyat berhak menentukan cara dan corak pemerintahan diselenggarakan, serta rakyatlah yang menejadi penentu tujuan yang ingin dituju oleh negara dan pemerintahan (Jimly Asshiddiqie, 2010:414).

Berdasarkan Undang-Undang Pemilu No. 10 Tahun 2008 jumlah anggota DPR sebanyak 560 orang,keanggotaan DPR diresmikan dengan keputusan presiden,anggota DPR berdomisili di ibu kota Negara, Masa jabatan anggota DPR adalah lima tahun dan berakhir pada saat anggota DPR yang baru mengucapkan sumpah/janji. Sebelum memangku jabatannya, anggota DPR mengucapkan sumpah/ janji secara bersama-sama yang dipandu oleh Ketua Mahkamah Agung dalam sidang paripurna DPR (Wisnu, 2015:27-28). 


\section{Ketatanegaraan Islam}

Ketika menelaah tata negara islam dalam perspektif sejarah tentunya kita tidak bisa terlepas dari perjalanan sejarah Rasulullah SAW saat beliau berada di Madinah. Sejarah Nabi SAW ketika di MakKah ternyata hubungannya lebih banyak dengan keadaan sosial yang penuh dengan penindasan dan perilaku menyimpang secara moralitas keagamaan.

Masyarakat yang kebanyakan kalangan yang meras tertindas oleh perilaku jahiliyah masyarakat Makah kemudian bersama Nabi SAW berhijrah dan menciptakan sebuah negara Madinah. Negara Madinah dapat didefinisikan sebagai suatu negara yang sesungguhnya karena telah memenuhi persyaratan sebuah negara yaitu; rakyat, wilayah, pemerintah dan perundang-undang. Hal pertama kali dilakukan oleh Nabi Muhammad SAW adalah membuat sejenis konstitusi yang lebih dikenal dengan Piagam Madinah. Menurut Nur Kholis Madjid, piagam madinah yang di susun oleh Rasulullah SAW itu memilki konsepsi dan dasar pembentukan negara modern saat ini. Dalam piagam madinah itu, untuk pertama kalinya telah disusun ide-ide tentang kebebasan beragama, hal setiap kelompok untuk pengaturan tata hidup sesuai dengan keyakinannya, kemerdekaan hubungan ekonomi antar golongan serta kewajiban bela Negara (Iqbal, 2016: 195-197).

Setidaknya ada empat cara Nabi Muhammad SAW dalam memutuskan suatu kebijakan atau keputusan politik (Syaiful, 2013:16-17):

a. Musyawarah dengan para sahabat

b. Meminta pertimbangan kalangan ahli/profesional

c. melemparkan masalah-masalah tertentu yang biasanya berdampak luas kepada masyarakat kepada forum yang lebih besar

d. mengambil keputusan sendiri.

\section{METODE}

Penelitian yang dilakukan terhadap syarat-syarat calon anggota legislatif ini, memerlukan identifikasi dan pemahaman yang mendalam untuk melihat konteks peristiwa politik yang melingkupi permasalahan penelitian dan proses yang terjadi dalam lembaga an legislatif. Oleh karena itu, penelitian yang dipakai adalah penelitian kualitatif dengan menggunakan studi literatur. Sebagaimana dikemukakan oleh Joseph A. Maxwell (1996:17-19), penelitian kualitatif antara lain ditujukan untuk memahami makna, memahami konteks partikular, mengantisipasi fenomena dan pengaruh yang tidak teratasi, serta memahami proses.

Penelitian ini akan mengidentifikasi problematika yang ditimbulkan lembaga legislatif dalam pelaksanaan peran dan fungsinya sebagai wakil rakyat. Penelitian ini juga akan mengidentifikasi bagaimana hukum ketatanegaraan islam menyajikan literatur terhadap polemik yang terjadi. Selanjutnya, penelitian ini akan memberikan rekomendasi berupa alternatif rekonstruksi terhadap lembaga legislatif yang ditujukan 
untuk mengoptimalkan peran dan fungsi lembaga legislatif agar penyelenggaraan pemerintahan dapat efektif dan berjalan dengan stabil.

\section{HASIL DAN PEMBAHASAN}

Lembaga perwakilan dalam konsep ketatanegaraan islam dikenal dengan istilah ahl al-hall wa al-'aqd yang dirumuskun oleh para ahli fiqih siyasah sebagai orang yang memipunyai kewenangan untuk menentukan dan memutuskan kebijakan atas kepentingan umat (warga negara). Hal itu menunjukkan, ahl al-hall wa al-'aqd adalah sebuah lembaga perwakilan yang mewadahi dan menyalurkan aspirasi atau suara rakyat (Iqbal, 2016:158-159). Lembaga perwakilan tersebut mengImplementasikan konsep Syura, pada konteks prinsip ketatanegaraan Islam yang berkaitan erat dengan upaya pelaksanaan pemerintahan yang baik (good governance), mengayomi kehidupan umat, dan melayani umat menuju kemaslahatan bersama (al-mașahat alammah) (Lukman, 2013: 116).

Sebelum masa Islam, orang-orang Arab memiliki suatu lembaga yang disebut dewan "Nadi", yaitu dewan yang senantiasa bermusyawarah untuk memutuskan suatu masalah. Lembaga inilah yang kemudian para ulama mendemonstrasikan dalam AlQur'an, dengan menggunakan istilah "nadi" atau "syura". Kekuatan tertinggi untuk mengambil keputusan tentang segala sesuatu di kalangan warga Arab, yang belum mengenal bentuk pemerintahan kerajaan, pemerintahan absolut atau otokratik itu, berada ditangan orang-orang tua dalam suku atau kota mereka (B.Budiarti, 2017:43).

Pada masa Rasul, ahl al-hall wa al- 'aqd terdiri dari para sahabat, yaitu mereka yang ditugaskan dibidang keamanan dan pertahanan serta urusan-urusan yang berkenaan dengan kemaslahatan umat, para sahabat yang sering beliau ajak musyawarah, mereka para al-Sabiqun al-Awwalun, dan sahabat yang memiliki pandangan luas dan kecerdasan serta menunjukkan perjuangan dan kesetiaan yang tinggi terhadap agama Islam, dan mereka yang berhasil menjalankan tugasnya baik dari kaum Ansar maupun dari kaum Muhajirin.

Jadi jelas bahwa pada zaman itu, orang-orang yang disebut sebagai ahl al-hall wa al- 'aqd secara terus menerus memegang kedudukan yang sangat dipercaya selama jangka waktu lama dan dengan demikian diberi hak untuk mengambil keputusankeputusan bersama mengenai semua massalah pemting yang menyangkut umat (B.Budiarti, 2017:44). Sehingga konsep ahl al-hall wa al- 'aqd dapat dikatakan sama dengan konsep Dewan Perwakilan Rakyat Republik Indonesia (DPR RI) pada sistem ketatanegaraan di Indonesia.

Berdasarkan Undang-Undang Dasar Tahun 1945 pasca amandemen, dalam menjalankan peran dan tugasnya sebagai lembaga perwakilan, DPR mempunyai fungsi anggaran, fungsi legislasi, dan fungsi pengawasan, yang dalam pelaksanaannya DPR juga diberikan hak secara kolektif berupa hak angket, hak interpelasi, serta hak untuk menyatakan pendapat (pasal 20a). Peran legislatif menjadi sangat fundamen, 
salah satunya adalah sebagai lembaga yang melaksanakan fungsi legislasi atau pembuat Undang-Undang.

Secara spesifik, DPR sebenarnya memiliki empat fungsi dasar sebagai salah satu lembaga tinggi negara yang menjalankan fungsi perwakilan, yaitu: Pertama, Fungsi Legislasi, Fungsi ini berkaitan dengan usaha untuk menyalurkan aspirasi rakyat menjadi keputusan dan kebijakan politik yang akan dilaksanakan oleh pemerintah (ekskutif). Di sini kapabilitas anggota DPR ditantang, Mereka harus mampu merencanakan dan memutukan arah serta tujuan pemerintahan sesuai dengan asasasas yang telah ditentukan. Kedua, Fungsi Pengawasan, fungsi yang berkenaan dengan usaha memastikan pelaksanaan keputusan dan kebijakan politik yang telah diambil tidak menyimpang dari tujuan dan arah yang telah ditentukan. Idealnya DPR bukan hanya mendeteksi penyimpangan atau kekeliruan yang bersifat prosedural, selain itu juga bisa mengetahui terjadinya kesalahan teknis, seperti perkara bangunan fisik yang daya tahannya tidak sesuai perkiraan normal. Ketiga, Fungsi Anggaran. Fungsi ini berkenaan dengan kewenangan DPR mendistribusikan anggaran dengan skala prioritas yang secara politis telah ditentukan. Keempat, Fungsi Representasi, Fungsi representasi DPR dapat digambarkan sebagai fungsi substantif yang melekat dalam diri DPR sebagai wakil rakyat yang diterimanya melalui pemilu (Solihah dan Witianti,2016:293-294).

Menurut Jimly Asshiddiqie yang menyebutkan bahwa dalam pelaksanaan di Indonesia, fungsi legislasi-lah yang dianggap utama, sedangkan fungsi selainnya, yakni fungsi pengawasan dan anggaran adalah fungsi kedua dan ketiga sesuai dengan urutannya dalam peundang-undangan. Padahal, ketiga-tiganya sama-sama penting. Bahkan di berbagai negara maju dewasa ini, yang lebih diutamakan adalah fungsi pengawasan dibandingkan fungsi legislasi. Hal ini dikarenakan sistem hukum di berbagai negara maju tersebut telah dipandang cukup untuk menjadi pedoiman penyhelenggaraan negara, sehingga tidak banyak lagi produk hukum (dalam bentuk UU) yang dibutuhkan (Abdul Bari, 2017:7-8).

Pergeseran fungsi legislasi hasil amendemen konstitusi tersebut memberi peluang yang besar bagi DPR untuk berkiprah secara optimal dalam ikut menentukan arah perjalanan bangsa dan negara ke depan, termasuk dalam mengajukan RUU dan berperan besar dalam pembentukan UU serta mengisi dan menentukan isi sebuah UU. Namun demikian harapan rakyat dan peluang yang diberikan konstitusi tersebut tidaklah dapat dijalankan secara optimal oleh DPR.

Hal ini dapat dilihat bahwa DPR periode 2009-2014 hasil Pemilu 2009 minimal mempunyai masalah besar dalam hal fungsi legislasi, yaitu kinerja pembentukan Undang- Undang (UU) yang rendah. Hal ini ditandai dengan sedikitnya jumlah UU yang dihasilkan per tahun dibandingkan dengan target pembentukan UU sebagaimana tercantum dalam Program Legislasi Nasional (Prolegnas) yang disusun oleh DPR itu sendiri (Abdul Bari, 2017:10). 
Melihat Data priode kebelakang menyebutkan bahwa dari Prolegnas priode 2005-2009 sebanyak 130 RUU, dapat direalisasikan sebanyak 76 RUU menjadi UU atau sebanyak 58,5\% (Ricko Wahyudi, 2011:72). Hal ini menunjukkan fungsi legislasi kurang berjalan maksimal.Pada priode selanjutnya Dalam fungsi legislasi, untuk pertama kal inya pada awal bulan November 2009 ditetapkan Prolegnas jangka menengah untuk periode 2009-2014. Dalam Prolegnas jangka menengah ini telah ditetapkan sebanyak 247 (dua ratus empat puluh tujuh) judul Rancangan UndangUndang yang direncanakan akan disusun dan dibahas dalam kurun waktu lima tahun. Tetapi DPR dalam perjalanannya khusus di sektor Legislasi, terjadi banyak inkonsistensi dan kelemahan karena DPR RI ternyata belum menghasilkan produk hukum yang sebagai mana ada dalam perencanaan. Inkonsistensi yang terjadi pada periode ini sebab pada jangka waktu lima tahun (2009-2014) Pemerintah dan DPR RI telah mengajukan Rancangan Undang-Undang di luar Daftar Rancangan UndangUndang Prolegnas 2009-2014 sebanyak lima Rancangan Undang-Undang (Kemenkumham,15 Oktober 2019).

Data yang besumber dari Forum Masyarakat Peduli Parlemen Indonesia menunjukkan, perolehan program legislasi DPR RI 2014-2019 lebih rendah jika dibandingkan dengan periode sebelumnya. Tercatat DPR periode 2014-2019 hanya mengesahkan Rancangan Undang-Undang (RUU) sebanyak 84 dengan jumlah komposisi 49 kumulatif terbuka dan 35 program legislasi nasional (Prolegnas).

Sekelumit permasalahan dan kurang maksimalnya berbagai fungsi yang dijalankan anggota DPR sejatinya terjadi karena kesalahan sistem pada konsepsi DPR itu sendiri. Anggota DPR RI yang berjumlah 550 (lima ratus lima puluh) orang berasal dari latar belakang status sosial dan bidang keilmuan yang berbeda-beda. Namun, kualitas mereka kurang berbobot karena banyak yang tidak mempunyai wawasan kebangsaan dan pengetahuan ketatanegaraan yang cukup, terutama dalam berbagai hal, seperti wawasan keparlemenan, penguasaan bidang legislasi, pengawasan, dan anggaran. Hal tersebut menjadi salah satu kendala karena anggota DPR akan bertindak untuk mewakili dan mewujudkan keinginan rakyat Indonesia dalam sebuah lembaga yang memiliki kearifan dam mampu menggalang keahlian, terutama dalam bidang legislasi (Arrista, 2013:250).

Permasalahan tersebut tentunya sejalan dengan sebuah hadits dari Rasulullah SAW riwayat oleh Imam Al-Bukhari :

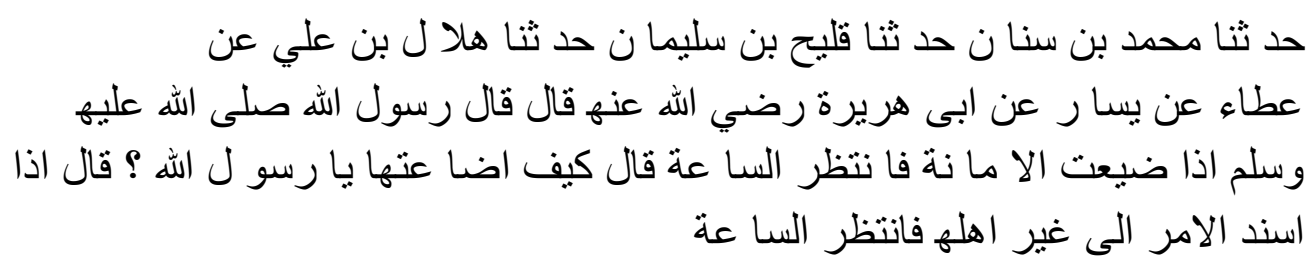


Imam al-Bukhari menyampaikan Muhammad bin Sinan meriwayatkan kepada kami, Qulaih bin Sulaiman telah meriwayatkan kepada kami, (riwayat itu) bersumber dari Atha', dari Yasar, dari Abu Hurairah RA yang berkata : Rasulullah SAW telah bersabda: Apabila suatu amanah telah disia-siakan, maka tunggulah saat kehancurannya. (Abu Hurairah) bertanya : Bagaimana menempatkan amanah itu, ya Rasulullah ? Beliau menjawab : Apabila suatu perkara diserahkan kepada orang yang bukan ahlinya, maka tunggulah saat kehancurannya"( Sri Harmonika,2017:6-7).

Mencermati hadits ini menarik karena hubungan antara amanah dengan keahlian menjadi sebuah subtansi. Kalimat "Apabila suatu urusan diserahkan kepada seseorang yang bukan ahlinya maka tunggulah saat kehancurannya" merupakan penjelasan untuk kalimat awal : "Apabila amanah disia-siakan, maka tunggulah saat kehancurannya." Hadits tersebut memberi sebuah peringatan secara perspektif manajerial karena amanah berarti menyerahkan suatu perkara kepada seseorang yang memiliki keahlian atau profesional.

Islam sangat memperhatikan esensi profesionalisme. Karena itulah, saat Nabi Muhammad SAW mengamanatkan tugas kepada para sahabatnya, sangat melihat dari latar belakang dan kapabilitas sahabat tersebut. Syarat-syarat anggota DPR sejatinya diatur dalam Peraturan Komisi Pemilihan Umum (PKPU) yang terbaru adalah PKPU Nomor 20 tahun 2018 tentang pencalonan anggota Dewan Perwakilan Rakyat (DPR), Dewan Perwakilan Rakyat Daerah (DPRD) Provinsi, dan Kabupaten/Kota pasal 7 yang berbunyi (www.dpr.go.id, 31 Januari 2020).

1. Bakal calon anggota DPR, DPRD Provinsi, dan DPRD Kabupaten/Kota adalah Warga Negara Indonesia dan harus memenuhi persyaratan:

a. telah berumur 21 (dua puluh satu) tahun atau lebih terhitung sejak penetapan DCT

b. bertakwa kepada Tuhan Yang Maha Esa;

c. bertempat tinggal di wilayah Negara Kesatuan Republik Indonesia;

d. dapat berbicara, membaca, dan/atau menulis dalam bahasa Indonesia;

e. berpendidikan paling rendah tamat sekolah menengah atas, madrasah aliyah, sekolah menengah kejuruan, madrasah aliyah kejuruan, atau sekolah lain yang sederajat;

f. setia kepada Pancasila, Undang-Undang Dasar Negara Republik Indonesia Tahun 1945, Negara Kesatuan Republik Indonesia, dan Bhinneka Tunggal Ika;

g. tidak pernah sebagai terpidana berdasarkan putusan pengadilan yang telah memperoleh kekuatan hukum tetap yang diancam dengan pidana penjara 5 (lima) tahun atau lebih berdasarkan putusan pengadilan yang telah berkekuatan hukum tetap;

h. sehat jasmani, rohani, dan bebas penyalahgunaan narkotika, psikotropika dan zat adiktif;

i. terdaftar sebagai pemilih;

j. bersedia bekerja penuh waktu; 
k. mengundurkan diri sebagai: 1) gubernur, wakil gubernur, bupati, wakil bupati, wali kota atau wakil wali kota; 2) kepala desa, 3) perangkat desa yang mencakup unsur staf yang membantu Kepala Desa dalam penyusunan kebijakan dan koordinasi yang diwadahi dalam Sekretariat Desa, dan unsur pendukung tugas Kepala Desa dalam pelaksanaan kebijakan yang diwadahi dalam bentuk pelaksana teknis dan unsur kewilayahan; 4) Aparatur Sipil Negara; 5) anggota Tentara Nasional Indonesia; 6) anggota Kepolisian Negara Republik Indonesia; 7) direksi, komisaris, dewan pengawas dan/atau karyawan pada Badan Usaha Milik Negara, Badan Usaha Milik Daerah, Badan Usaha Milik Desa, atau badan lain yang anggarannya bersumber dari keuangan negara;

1. mengundurkan diri sebagai Penyelenggara Pemilu, Panitia Pemilu, atau Panitia Pengawas;

m. bersedia untuk tidak berpraktik sebagai akuntan publik, advokat, notaris, pejabat pembuat akta tanah, atau tidak melakukan pekerjaan penyedia barang dan jasa yang berhubungan dengan keuangan negara serta pekerjaan lain yang dapat menimbulkan konflik kepentingan dengan tugas, wewenang, dan hak sebagai anggota DPR, DPRD Provinsi, dan DPRD Kabupaten/Kota sesuai dengan ketentuan peraturan perundang-undangan;

n. bersedia untuk tidak merangkap jabatan sebagai pejabat negara lainnya, direksi, komisaris, dewan pengawas dan/atau karyawan pada Badan Usaha Milik Negara, Badan Usaha Milik Daerah, Badan Usaha Milik Desa, atau badan lain yang anggarannya bersumber dari keuangan negara;

o. menjadi anggota Partai Politik;

p. dicalonkan hanya di satu lembaga perwakilan;

q. dicalonkan hanya oleh satu Partai Politik;

r. dicalonkan hanya di satu Dapil; dan

s. mengundurkan diri sebagai anggota DPR, DPRD Provinsi, atau DPRD Kabupaten/Kota bagi calon anggota DPR, DPRD Provinsi, atau DPRD Kabupaten/Kota yang dicalonkan oleh Partai Politik yang berbeda dengan Partai Politik yang diwakili pada Pemilu Terakhir.

Persyaratan yang diatur dalam PKPU dapat ditelisik bahwa syarat anggota DPR dari segi pendidikan hanya dibatasi pada batas minimum lulus dari tingkat Sekolah Menengah Atas (SMA) sederajat dan pada konsepsi kemampuan atau skill tidak diutamakan hanya dicantumkan dapat berbicara, membaca, dan/atau menulis dalam bahasa Indonesia. Lebih lanjut jika dibandingkan dengan konsepsi Ahl Al-Hall Wa Al$A q d$, para ulama mempunyai berbagai padangan tentang syarat siapa yang berhak mengisi struktur Ahl Al-Hall Wa Al-Aqd, An-Nawawi pada kitab Al-Minhaj Ahl Halli Wa al 'Aqd adalah ulama, para kepala, pemuka masyarakat yang menjadi unsur-unsur masyarakat yang berusaha mencapai kemaslahatan rakyat (Alwi, 2018:59). Selain itu, Muhammad Abduh, meberi kesamaan Ahl-al-Hall Wa al- 'Aqd dengan Ulil Amri yaitu 
orang-orang yang profesional dalam berbagai keahlian di masyarakat, mereka adalah orang-orang yang memiliki kapabilitas yang telah teruji. Sehingga Ulil Amri tersebut merupakan golongan Ahl-Al-Hall Wa Al-'Aqd dari kalangan muslim yang kredibilitasnya teruji. Mereka adalah para hakim, amir, ulama, militer dan seluruh pemimpin yang dijadikan panutan oleh umat Islam yang orientasinya pada kepentingan dan kemaslahatan publik (Alwi, 2018:59).

Sementara itu, Rasyid Ridha berpendapat bahwa ulil amri adalah Ahl-al-Hall Wa al- 'Aqd. Ia menyampaikan "kumpulan ulil amri dan mereka yang disebut Ahl alHall Wa al-'Aqd adalah mereka yang diberi kepercayaan oleh umat yang terdiri dari para ulama, para pemimpin militer, para pemimpin pekerja untuk kemaslahatan publik seperti pedagang, tukang, petani, para pemimpin perusahaan, para pemimpin partai politik dan para tokoh wartawan (Nurul, 2016:62). Lebih lanjut, Al-Maraghi memberi rumusan sama seperti yang dikemukakan oleh Muhammad Abduh dan Rasyid Ridha.

Sementara Al-Mawardi lebih merincikan syarat-syarat orang yang berhak mengisi Ahl Al-Hall Wa Al-Aqd yang juga disebut oleh Al Mawardi yaitu ahl-ikhtiyar harus mempunyai tiga syarat: (1) kredibilitas pribadinya atau keseimbangan (al'adâlah) memenuhi semua kcriteria; (2) mempunyai ilmu; (3) memiliki pendapat yang kuat dan hikmah (Rashda, 2017:168-169).

Muhammad Tahir Ibnu "Ashur: " Ahl Al-Hall Wa Al-Aqd adalah para pakar ilmuan dan ahli amanah di sebuah negara Islam yang bertempat di ibukota negara khalifah dan termasuk di dalamnya Pimpinan tentera." Lembaga legislatif menurut beliau terdiri dari para ilmuan dan ahli-ahli kuasa yang memiliki watak amanah dalam melaksanakan tugas. Sedangkan Zafir al-Qa-simiy menyifatkan ahl halli wal al aqd sebagai para ahli fiqih yang dapat berijtihad, kepakaran dalam bidang fiqih dan kemampuan berijtihad adalah syarat utama menurut za' far (Nadirsah, 2011:52-53).

Abdul Aziz Al khayyat mengatakan bahawa syarat ahli badan legislatif Islam adalah; Islam, adil, jujur,iffah (menjaga marwah), baligh dan rashi (boleh membezakan yang baik) sedangkan syarat yang paling rendah adalah apabila kebaikan lebih banyak daripada keburukannya. Mengikut Mazhab Hanafiyah dan Hadawiyah (syiah) dibenarkan bagi orang bukan Islam untuk menjadi ahli badan ini dengan syarat dia memahami ajaran Islam dan dapat berbuat adil.

Mahmud al-Khalidiy berkata: "Setiap orang yang hidup di bawah naungan Negara Islam dan taat kepada hukum-hakamnya layak untuk menjadi ahli dalam Majlis Syura apabila dia sudah baligh, berakal, sama ada laki-laki atau perempuan, muslim atau bukan muslim"Sedangkan Imam Qalqashandiy memberikan tiga syarat bagi ahli badan legislatif Islam iaitu berilmu pengetahuan, adil dan berwawasan sepertimana yang dikatakan oleh Imam al-Mawardiy

Sementara Abu Fariz menyebutkan syarat-syarat dengan agak sedikit sempit sebagaimana yang dinyatakan di dalam kitabnya. Antara syarat-syarat yang disebutkannya iaitu mukallaf, sehingga tidak dibenarkan orang bukan Islam menjadi ahli badan ini kerana bukan termasuk orang yang terkena taklif (beban), merdeka, laki- 
laki, berwawasan, bermoral tinggi, menetap di ibu negara dan tidak mencalonkan diri (Nadirsah, 2011:58-59).

Pemikiran-pemekiran tentang legislatif terus berkembang, beberapa ulama kontemporer juga memberi pandangan tentang siapa yang seharusnya menduduki kursi legislatif. Menurut Muhammad Iqbal lembaga legislatif tidak hanya diduduki oleh ulama yang di anggap memiliki otoritas dalam penafsiran ajaran islam, lembaga legislatif harus diisi oleh, menurut Iqbal sendiri "orang awam tentang hukum islam tetapi mempunyai pandangan yang tajam terhadap berbagai persoalan kemasyarakatan" (Iqbal, 2016:199). Sedangkan menurut Abdul Wahab Khallaf orangorang yang duduk dilembaga legislatif ini terdiri dari para mujtahid dan ahli fatwa (mufti) serta para pakar dalam berbagai bidang (Febrianty, 2014:62). Berdasarkan beberapa pendapat para ulama tersebut penulis merincikan dengan bentuk sistematis tabel sebagai berikut:

Table 1. Pendapat para ahli tata negara islam

\begin{tabular}{|c|c|c|c|}
\hline Tokoh & Agama & Latar Belakang & Kriteria Sifat \\
\hline An-Nawawi & & $\begin{array}{l}\text { Ulama Pemuka } \\
\text { Masyarakat }\end{array}$ & $\begin{array}{l}\text { Memiliki komitmen } \\
\text { kepada Rakyat }\end{array}$ \\
\hline $\begin{array}{l}\text { Muhammad } \\
\text { Abduh }\end{array}$ & & $\begin{array}{l}\text { Profesional, Ahli, } \\
\text { Ulama,amir, hakim, } \\
\text { militer }\end{array}$ & $\begin{array}{l}\text { Berorientasi kepentingan } \\
\text { publik }\end{array}$ \\
\hline Rasyid Ridha & & $\begin{array}{l}\text { Ulama,militer, } \\
\text { pemimpin } \\
\text { perusahaan, } \\
\text { pimpinan parpol, } \\
\text { wartawan } \\
\end{array}$ & $\begin{array}{c}\text { Berorientasi kepentingan } \\
\text { publik, Mendapat } \\
\text { kepercayaan rakyat }\end{array}$ \\
\hline Al-Mawardi & & $\begin{array}{l}\text { Mempunyai ilmu } \\
\text { (Ahli) }\end{array}$ & $\begin{array}{l}\text { Punya pemikiran visioner } \\
\text { (ahli hikmah), Kredibil }\end{array}$ \\
\hline $\begin{array}{l}\text { Tahir Ibnu } \\
\text { 'Ashur }\end{array}$ & & $\begin{array}{c}\text { Para ahli } \\
\text { Pemimpin, } \\
\text { pimpinan militer, } \\
\text { ilmuan }\end{array}$ & Amanah \\
\hline $\begin{array}{l}\text { Abdul Aziz Al } \\
\text { khayyat }\end{array}$ & Islam & & $\begin{array}{c}\text { Adil, jujur, baligh dan } \\
\text { rashi }\end{array}$ \\
\hline $\begin{array}{l}\text { Mahmud al- } \\
\text { Khalidiy }\end{array}$ & $\begin{array}{c}\text { Islam/non } \\
\text { muslim }\end{array}$ & Laki2/perempuan & $\begin{array}{l}\text { Baligh, berakal, taat } \\
\text { kepada hukum }\end{array}$ \\
\hline $\begin{array}{c}\text { Imam } \\
\text { Qalqashandiy }\end{array}$ & islam & $\begin{array}{l}\text { Berilmu } \\
\text { pengetahuan }\end{array}$ & $\begin{array}{l}\text { Sependapat dengan al } \\
\text { mawardi adil dan } \\
\text { berwawasan }\end{array}$ \\
\hline Abu Fariz & Islam & Mukallaf & $\begin{array}{c}\text { merdeka, laki-laki, } \\
\text { berwawasan, bermoral } \\
\text { tinggi, menetap di ibu } \\
\text { negara dan tidak } \\
\text { mencalonkan diri }\end{array}$ \\
\hline $\begin{array}{l}\text { Muhammad } \\
\text { Iqbal }\end{array}$ & & & $\begin{array}{c}\text { Memiliki pandangan luas } \\
\text { tentang sosial } \\
\text { kemasyarakatan }\end{array}$ \\
\hline
\end{tabular}


Terakreditasi Nasional Sinta 4: SK. No.30/E/KPT/2019

\begin{tabular}{|c|c|c|c|}
\hline Tokoh & Agama & Latar Belakang & Kriteria Sifat \\
\hline $\begin{array}{c}\text { Abdul Wahab } \\
\text { Khallaf }\end{array}$ & $\begin{array}{c}\text { Ahli fatwa, } \\
\text { mujtahid, Pakar } \\
\text { diberbagai bidang }\end{array}$ & Berilmu \\
\hline
\end{tabular}

Sumber: Hasil Olahan Peneliti , 2019

Data tersebut menyajikan, dari literatur sebelas tokoh yang dimuat dalam tulisan ini pendapatnya hanya empat tokoh yang mencantumkan secara eksplisit keharusan beragama islam, sedangkan kesemuanya memperioritaskan kriteria orang yang berhak mengisi lembaga legislatif bertumpu pada aspek keahlian dan sifat yang terpuji atau terpercaya. Keahlian dan keilmuan menjadi aspek paling penting dari pendapat tersebut. Salah satu hal yang patut ditelisik, adanya kriteria pakar ahli atau memiliki keahlian yang dikemukakan sejatinya coba diterapkan pada implementasi lembaga legislatif di Indonesia. DPR mengangkat staf ahli atau tenaga ahli yang kemudian di harapkan membantu kinerja DPR.

Tenaga ahli bertugas untuk membantu kerja legislator di parlemen Mereka diharapkan mampu meningkatkan performa legislator dengan profesionalitas kerja yang dimilikinya Kriteria profesionalitas yang digunakan oleh Paul Webb dan Robin Kolodny dalam konteks tenaga ahli yang mendukung kerja kerja politik antara lain kompetensi otonomi mobilitas aturan regulasi dan komitmen. Pada tahun 2007 Sekretariat Jenderal DPR memberikan fasilitas yakni satu tenaga ahli kepada setiap legislator Pengadaan pos tenaga ahli ini dimaksudkan agar mendongkrak kinerja lembaga legislatif yang belum membaik setelah diberikan anggaran untuk mengangkat satu asisten pribadi Rekrutmen tenaga ahli dilakukan oleh Setjen DPR dengan mengadakan serangkaian tes administrasi wawancara dan psikologi 25 Tenaga ahli tersebut statusnya kontrak selama setahun dan tiap tahunnya ada evaluasi Gaji yang diberikan oleh Setjen DPR kepada tiap tenaga ahli adalah 7.500000 rupiah per bulannya untuk 550 orang ( Permana dan Adaba,2016:87).

Pada perjalanannya, peran tenaga ahli masih dinilai kurang efektif dan menemui berbagai permasalahan. Mulai dari kurang jelas dan rincinya aturan tentang tenaga ahli anggota baik melalui UU MD3 maupun aturan Tata Tertib DPR 2009 menyebabkan munculnya distorsi dalam pelaksanaan Dalam UU MD3 sebagai payung hukum tertinggi ten tang tenaga ahli hanya menyebutkan kelompok pakar dan tim ahli pada pasa180 dan 395, Ketidakjelasan aturan operasional tenaga ahli anggota ini memicu penafsiran dan pemak naan yang beragam baik dari anggota dewan maupun partai politik Banyak anggota dewan yang kemudian mengangkat sanak saudaranya sebagai tenaga ahli anggota yang honor per bulannya ditanggung negara tersebut Bahkan ada tenaga ahli yang melakukan outsource dengan mempekerjakan orang lain untuk melakukan tugas tugas tenaga ahli( Permana dan Adaba,2016:94).

Permasalahan tersebut bertentangan dengan konsep ketatanegaraan islam, islam sendiri telah meletakkan prinsip profesionalisme dan akuntabilitas publik dalam masalah pengisian jabatan pemerintahan. Dalam prinsip ini, pemegang kekuasaan 
tidak boleh mengangkat pejabat-pejabat negara berdasarkan hubungan primordial atau kekerabatan (Iqbal, 2016:240).

Atas dasar permasalahan itu dan disertai kurang maksimalnya kinerja DPR selaku lembaga legislatif di Indonesia, dapat dikonklusikan bahwa dengan penambahan tenaga ahli pun belum menjadi sebuah solusi yang komprehensif dalam permasalahan yang terjadi di lembaga legislatif saat ini. Pandangan konsep syarat anggota lembaga legislatif ini dalam perspektif ketatanegaraan islam bisa menjadi pertimbangan untuk menjadi sebuah granddesign syarat-syarat anggota legislatif dalam rangka meningkatkan kapabilitas dan pemaksimalan kinerja perwakilan rakyat.

Perwujudan peningkatan kapabilitas anggota DPR harus di kontruksi melalui perubahan dan penambahan syarat-syarat anggota DPR yang saat ini tertuang dalam PKPU Nomor 20 tahun 2018 idealnya harus diperbaharui dengan tujuan agar berbagai fungsi yang dimiliki. Muaranya adalah DPR benar-benar menjadi reperesentasi dari kehendak rakyat.

Prinsip profesionalitas, kemampuan dan kejujuran yang diangkat dalam AlQur'an surat al-Qasash, 28:26, melalui kisah Nabi Musa, Allah mengisyaratkan bahwa orang yang diangkat sebagai pejabat harus mempunyai dua syarat, yaitu kuat (dalam artian memiliki kemampuan dan keahlian dibidangnya) dan terpercaya (dapat menjaga amanah yang diserahkan kepadanya) (Iqbal, 2016:240). Atas dasar itulah harus dilahirkannya ius constituendum syarat-syarat anggota legislatif baik itu DPR RI, DPRD Provinsi maupun DPRD Kabupaten/Kota sesuai dengan kriteria keahilian dibidangnya.

Fungsi-fungsi yang diamanatkan dalam UUD NRI 1945 bisa di desain pada konsep ini. Pada fungsi legislasi karena fungsinya dan tujuannya adalah dalam rangka pembentukan undang-undang yang tentunya harus sesuai dan sejalan dengan kepentingan umum, maka diperlukan orang-orang yang ahli dibidangnya seperti pakar ilmu hukum, perudang-undangan, maupun sarjana dibidang hukum tata negara. Fungsi anggaran dalam menjalankannya diperlukan ahli-ahli dibidang keuangan, ahli dibidang manajemen keungan dan para sarjana ekonomi. Selanjutnya pada fungsi pengawasan karena pada fungsi ini berkaitan dengan upaya memastikan pelaksanaan keputusan politik yang telah diambil tidak menyimpang dari arah dan tujuan yang telah ditetapkan maka diperlukan ahli dalam bidang kebijakan publik, seorang negarawan termasuk seorang ulama yang memiliki pandangan luas terhadap negara bangsa.

\section{E. KESIMPULAN}

Syarat dan kriteria anggota DPR yang diterapkan di Indonesia saat ini yang tertuang dalam PKPU Nomor 20 tahun 2018 belum menjadi regulasi yang membuat terjaminnya kapabilitas dan kualitas anggota DPR di Indonesia. Berbagai kekisruhan yang terjadi di lembaga legislatif tersebut mulai dari tidak maksimalnya beberapa fungsi yang diamanatkan oleh UUD NRI 1945 seperti kurang produktifnya fungsi 
legislasi sampai produk legislasi yang bertentangan dengan niali-nilai yang hadir dimasyarakat menjadi persoalan yang harus ditelisik dan diatasi.

Permasalahan tersebut ternyata telah dijawab dalam konsep lembaga legislatif dalam ketatanegaraan islam. Profesonalisme dan keahlian pada bidang bidang yang diperlukan didalam DPR untuk menjalankan tugas-tugasnya adalah hal yang menjadi grand design agar terciptanya kerja yang maksimal. Adapun konsep yang menjadi ius constituendum kriteria anggota DPR adalah Pada fungsi legislasi diperlukan orangorang yang ahli dibidang ilmu hukum, perudang-undangan, maupun sarjana dibidang hukum tata negara. Fungsi anggaran dalam menjalankannya diperlukan ahli-ahli dibidang keuangan, ahli dibidang manajemen keungan dan para sarjana ekonomi. Pada fungsi pengawasan diperlukan ahli dalam bidang kebijakan publik, seorang negarawan termasuk seorang ulama yang memiliki pandangan luas terhadap negara bangsa. Hal yang tak kalah penting adalah sifat kepribadian dari anggota yang akan mengisi lembaga legislatif itu sendiri, yaitu benar-benar berorientasi untuk kemaslahatan masyarakat.

\section{DAFTAR PUSTAKA}

Alwi, Mochamad Amaludhin.( 2018). "Fungsi legislasi Dewan Perwakilan Daerah dalam sistem bikameral di Indonesia perspektif fiqih siyasah dusturiyah: studi pasca berlakunya undang-undang nomor 17 tahun 2014 tentang MPR, DPR, DPD dan DPRD.” Tesis, UIN Sunan Ampel Surabaya.

Arrista Trimaya. (2013) “Kinerja Fungsi Legislasi DPR RI Masa Bakti 2009-2014” Jurnal Legislasi Indonesia, 10 (3), 245 - 258.

Azed, Abdul Bari. (2017). "Menyoroti Kinerja Legislasi DPR.” Legalitas: Jurnal Hukum 6 (1) , 1-31.

Budiarti, B. (2017) "Studi Siyasah Syar'iyah Terhadap Konsep Legislatif Dalam Ketatanegaraan Islam.” Zawiyah: Jurnal Pemikiran Islam, 3 (2), 39-58.

Diana, Rashda. (2017) “Al-Mawardi dan Konsep Kenegaraan dalam Islam." Tsaqafah, 13(1) , 157-176.

Febrianty, Nurul Faristin Hesti. (2016). "Hak Imunitas Anggota Dpr Dalam Pasal 224 Undang-Undang No. 17 Tahun 2014 Perspektif Hukum Islam.” Tesis, UIN Sunan Ampel Surabaya.

Harmonika, Sri. (2017). "Hadits-Hadits tentang Manajemen Sumber Daya Manusia (SDM).” At-Tadbir: Jurnal Manajemen Pendidikan Islam, 1 (1), 1-14.

Hawari, Nadirsah. (2011). “As-Sulthah At-Tasyri'iyyah Dalam Perspektif Fiqh Siyasi Dan Qanun Wadh'iy.” Jurnal Tapis: Jurnal Teropong Aspirasi Politik Islam, 7 (1), 63-78. 
Hidayat, Syaiful. (2013). “Tata Negara dalam Perspektif Fiqih Siyasah”. Jurnal Tafaqquh, 1 (2).

http://ditjenpp.kemenkumham.go.id . “jurnal Legislasi Indonesia” di akses 15 Oktober 2019

http://www.dpr.go.id/berita/detil.id. "PKPU Harus Selaras Dengan UU yang Berlaku" di akses 31 Januari 2020

Ichwanuddin, Wawan.(2014) Legislatif Indonesia. Jakarta: Universitas Terbuka

Iqbal, Muhammad. (2016). Fiqh Siyasah Konstekstualisasi Doktrin Politik Islam. Jakarta:Kencana.

Permana, Yogi Setya, dan Pandu Yuhsina Adaba. (2016) "Menelisik Peran Tenaga Ahli Anggota Legislatif.” Jurnal Penelitian Politik , 8 (1), 12.

Sastra, Irmayadi. (2018). "Rekonstruksi Pencalonan Anggota Legislatif Melalui Tahapan Uji Kompetensi (Fit And Proper Test) Dalam Rangka Membangun Kapabilitas Anggota Legislatif." Tesis, University Of Muhammadiyah Malang.

Santoso, Lukman (2013) "Eksistensi Prinsip Syura Dalam Konstitusional Islam”. Jurnal Agama dan Hak Azazi Manusia, 3(1).

Sjadzali, Munawir.(1990) Islam dan tata negara: ajaran, sejarah, dan pemikiran. Jakarta:Penerbit Universitas Indonesia.

Solihah, Ratnia, dan Siti Witianti. (2016) "Pelaksanaan Fungsi Legislasi Dewan Perwakilan Rakyat Pasca Pemilu 2014: Permasalahan Dan Upaya Mengatasinya." CosmoGov: Jurnal Ilmu Pemerintahan, 2(2), 291-307.

Wahyudi, Ricko. (2011). "Pembaruan hukum agraria melalui rancangan UU bidang hukum agraria dalam program legislasi nasional 2010-2014." Tesis, Universitas Indonesia. Fakultas Hukum.

Wisnu, Jaya. (2015). “Kewenangan Dewan Perwakilan Rakyat Republik Indonesia Dalam Rekrutmen Hakim Agung Sebelum Dan Sesudah Ada Keputusan Mahkamah Konstitusi Nomor 27 /Puu-Xi/2013” Skripsi Fakultas Hukum Universitas Negeri Semarang. 